\title{
The Analysis of Outpatient Average Cost for Diabetes Mellitus Type II at Sanjiwani Hospital, Gianyar
}

\author{
Anny Eka Pratiwi ${ }^{1}$ and Kartika Sari ${ }^{2}$ \\ \{annie.pratiwi@gmail.com ${ }^{1}$ and kartikadharma@gmail.com² \\ Public Health Department, Universitas Warmadewa, Denpasar-Bali, Indonesia ${ }^{1}$ and Physiology and \\ Biochemistry Department, Universitas Warmadewa, Denpasar-Bali, Indonesia ${ }^{2}$
}

\begin{abstract}
The study design took upon cross sectional and mix method approach. The quantitative data are collected through questionnaire method, while the qualitative data are collected through in-depth interview method. The samples are 96 subjects that infected with the DM type II. The finding shows medical cost that paid by the patients classified into the prescription cost and laboratory cost. Indirect cost component paid by the patients is the transportation cost in reaching the health facility. Prescription and laboratory cost are the highest direct medical cost that took toll on the patient. The average cost paid by the Diabetes Mellitus type II patients are Rp. 548.200,-, transportation cost of Rp. 60.300,- and income loss of Rp.363.200,- for every month per person. There is a significant relationship of education, household income, and social economy status with the direct cost, while the indirect cost only has a significant relationship with household income, and social economy status.
\end{abstract}

Keywords: Average cost; diabetes mellitus type II; health insurance

\section{Introduction}

The Household Health Survey in 2001 shows the prevalence of Diabetes Mellitus for people is around 25 - 64 years old in Java and Bali in 7,5\%. Bali has become one of provinces with the largest cases of Diabetes Mellitus [1]. Gianyar regency is the region with the lowest prevalence of Diabetes Mellitus cases.

The number of Diabetes Mellitus cases in Indonesia has risen significantly from $1,1 \%$ in 2007 to $2,1 \%$ in 2013 [2,3].

The high prevalence and its complication tendency has put DM as a non-contagious disease that creates a significant economy burden to the health cost system [4]. Medical cost analysis is an important element in judging chronic disease, since it may evaluate the medical cost and illustrate disease that require an increase of resource allocation of prevention and therapy [1].

Diabetes Mellitus has reached the third largest number of non-contagious disease occurrence in Gianyar regency. The cost resulted by this disease is quite substantial, which took tool on the patients. Moreover, the government also has to prepare sufficient budget to ease the cost of these patients.

The number of death caused by Diabetes Mellitus in 2016 and 2017 are 9 people and 90 people respectively. The rise of Diabetes Mellitus cases in Gianyar regency was seen from the occurrence in 2016 to 2017. There are 952 cases in 2016 that increase into 11.070 cases in $2017[5]$. 
The high number of DM cases can be affected by several factors such as lifestyle, genetic, level of stress, as well as lack of physical activity. The people comprehension of a healthy life is required to diminish the possibility of infected with such diseases.

A number pf studies has revealded that health care for people suffering diabetes mellitus is somewhat considerable $[6,7,8,9,10]$. This indicates that the diabetes mellitus is one of the tramendous deseases to overcome. And in regard to the previous studies discoveries, we made an effort to reveal the cost of outpatient operating of diabetes mellitus suffered by a number of patients at Sanjiwani Hospital, Bali - Indonesia. Additionally, we implicitly intended to reveal how vulnenable the diabetes mellitus incidence to be occurred in the said locus.

This study uses questionnaires to collect the data related to the outpatient average medical cost paid. Costs taken into measure are the direct and indirect medical cost, as well as indirect cost related with medical treatment of the Diabetes Mellitus type II. In-depth interview was also used in this research to investigate the patients' perception of medical cost paid for DM type II.

Method used in this research was mixed method. Quantitative method was used to calculate the number of out patients medical cost of Diabetes Mellitus type II at RSUD Sanjiwani Gianyar. Qualitative method was used to investigate the patients' perception of economic burden taken by the DM type II outpatients at RSUD Sanjiwani Gianyar.

The research design used is cross sectional with descriptive approach. The research method taken in this research is a mixed method of quantitative and qualitative method.

The research site was at Sanjiwani Hospital in Gianyar. Sanjiwani hospital is one of the government health facilities. This hospital provides inpatient and outpatient treatment for Diabetes Mellitus patients.

The population of this research is Diabetes Mellitus patients that have been medically diagnosed by the doctors. Diabetes Mellitus patients that were treated, already have their medical record traced to assure their medical indication.

The data were taken in one medical facility during the month of May up to August 2018 by using valid questionnaires that have already tested in different samples. Questionnaires data were gathered by accidental sampling method. The in-depth interview data was using purposive sampling method.

Out of 106 samples, there are 10 samples that were taken out of this research. The sample calculation was using software in 2010 from the World Health Organization. The qualitative research samples taken were 15 people that used to increase the depth of patient perception towards the cost paid.

Several steps done in the statistic data analysis are:

- Characteristics Identification of Diabetes Mellitus Outpatients and its grouping to the cost classification

- Cost classifications are tested to acquire the average cost based on the cost classification. Every cost classification was described through its highest cost classification paid by Diabetes Mellitus Type II patients at RSUD Sanjiwani Gianyar.

- The data analysis was reported in the research findings analysis

\section{Qualitative Analysis}

In this research, qualitative analysis was done with source Triangulation method. Interview result was analyzed through editing, coding and data cleaning. 


\section{Result and Discussion}

The first test was done by looking at the patients characteristics that underwent medication at Sanjiwani Hospital in Gianyar. The univariate test result was shown as follows.

Table 1. The Characteristics of Diabetes Mellitus Type II Patients at Sanjiwani Hospital Gianyar.

\begin{tabular}{ll}
\hline Characteristics & $\begin{array}{l}\text { DM Type II Patients } \\
\text { Gianyar } \\
(\mathbf{n}=\mathbf{9 6})\end{array}$ \\
\hline Sex & $64(66,7)$ \\
\hline - Male & $33(33,3)$ \\
\hline - Female & \\
\hline Age & $28(29,2)$ \\
\hline$<45$ th & $68(70,8)$ \\
\hline$\geq 45$ th & $17(17,7)$ \\
\hline Education & $0(0)$ \\
\hline - Middle High School & $79(82,3)$ \\
\hline - Diploma & $89(92,7)$ \\
\hline - Bachelor & $7(7,3)$ \\
\hline - Employee & $49(51,0)$ \\
\hline - Unemployment & $47(49,0)$ \\
\hline
\end{tabular}

The number of Diabetes Mellitus Type II patients was mostly male with the age of above 45 years old, mostly in bachelor education degree, actively employed and mostly used National Health Services. The mean age of detection suggests delay in diagnosis of diabetes mellitus and accompanying complications, which has cost implications. Policy that enhances early detection of diabetes in clinical practice would therefore improve management and reduce costs. The benefit package consists of basic health care and covers about $95 \%$ of the diseases in Ghana. Provider payment methods used by the District Mutual Health Insurance 
Schemes are the Diagnosis Related Groups for services only and Itemized Fee for Service to pay for medicines on the National Health Insurance Scheme drug list [11].

Table 2. Cost Classifications and Average Cost Paid by Diabetes Mellitus Type II Patients at Sanjiwani Hospital Gianyar.

\begin{tabular}{|c|c|}
\hline Cost Classifications & Mean (SD) \\
\hline \multicolumn{2}{|l|}{ Direct Medical Cost } \\
\hline - Hospital Administration Cost & $10.2(2.3)$ \\
\hline - Medical Cost & $548.2(423.9)$ \\
\hline - Doctor Treatment Cost & $13.2(6.7)$ \\
\hline $\begin{array}{l}\text { - Medical Cost other than the } \\
\text { prescription }\end{array}$ & $7.9(3.7)$ \\
\hline - Ambulance Cost & $165.3(137.7)$ \\
\hline - Laboratory Cost & $515.8(807.9)$ \\
\hline \multicolumn{2}{|l|}{ Indirect Medical Cost } \\
\hline $\begin{array}{l}\text { - Transportation Cost (Treatment } \\
\text { Trip) }\end{array}$ & $60.3(43.8)$ \\
\hline - Clothing Cost & $2.6(1.1)$ \\
\hline - Food Cost & $3.5(4.0)$ \\
\hline - Family Visit Cost & $3.2(2.2)$ \\
\hline - Transfer Location Cost & $2.8(1.7)$ \\
\hline $\begin{array}{l}\text { - Supplementary Cost } \\
\text { (Ambulance fee, Cigarettes, } \\
\text { Deposit Money) }\end{array}$ & $8.4(5.2)$ \\
\hline \multicolumn{2}{|l|}{ Indirect Cost } \\
\hline - Income Loss (Patient) & $363.2(576.3)$ \\
\hline - Productivity Loss (Patient) & $73.4(102.0)$ \\
\hline - Time Loss (Patient) & $3.1(3.6)$ \\
\hline - Income Loss (Family Member) & $46.1(27.8)$ \\
\hline $\begin{array}{l}\text { - Productivity Loss (Family } \\
\text { Member) }\end{array}$ & $54.9(30.1)$ \\
\hline - Time Loss (Family Member) & $3.1(1.8)$ \\
\hline
\end{tabular}

The highest cost classification paid by Diabetes Mellitus patients is direct medical cost of medical (prescription) cost, while the indirect medical cost is its transportation cost. The 
indirect cost paid by the patients is the costs that appear due to the loss of income. The average cost paid by Diabetes Mellitus type II patients for medical cost is Rp.548.200,-, transportation cost is Rp.60.300,- and an income loss of Rp.363.200,-. Patients losses their income when they cannot work. Income loss is an additional cost that will be paid by the patient. Patients' productivity has decreased when they suffer DM. Therefore, patients have to control their blood sugar level by routinely taking medication to the health facility. A comprehensive cost analysis of expenditures incurred in the treatment of DM in Singapore. The results indicated that both medications and DM complications were strong determinants of costs. With projected increase in diabetes prevalence coupled with obesity and growing need for medical treatment in Singapore, diabetes will continue to be a heavy burden on health budgets [12]. The mean service cost constituted $22 \%$ and the direct medical cost constituted $78 \%$ of the mean financial cost. Drug cost was $71 \%$ of the financial cost, representing the highest cost component of diabetes management to the clinics [11]. Indirect costs include increased absenteeism ( $\$ 5$ billion) and reduced productivity while at work ( $\$ 20.8$ billion) for the employed population, reduced productivity for those not in the labor force ( $\$ 2.7$ billion), inability to work as a result of diseaserelated disability ( $\$ 21.6$ billion), and lost productive capacity due to early mortality ( $\$ 18.5$ billion) [13].

Table 3. The Relationship of Characteristics and Social Demography to the Direct and Indirect Cost Paid by the Diabetes Mellitus Type II Patients at RSUD Sanjiwani.

\begin{tabular}{|c|c|c|c|c|}
\hline \multirow[t]{2}{*}{ Characteristics } & \multicolumn{2}{|c|}{ Direct Cost } & \multicolumn{2}{|c|}{ Indirect Cost } \\
\hline & Mean (SD) & $\begin{array}{c}\mathrm{P} \\
\text { Value } \\
\end{array}$ & $\begin{array}{c}\text { Mean } \\
(\mathrm{SD})\end{array}$ & P Value \\
\hline \multicolumn{5}{|l|}{ Age } \\
\hline$<45$ th & $\begin{array}{c}1277.6 \\
(1437.4)\end{array}$ & & $\begin{array}{c}153.9 \\
(402.7)\end{array}$ & \multirow{2}{*}{0.147} \\
\hline$\geq 45$ th & $\begin{array}{c}1473.7 \\
(1555.9)\end{array}$ & 0.07 & $\begin{array}{c}150.9 \\
(332.1)\end{array}$ & \\
\hline \multicolumn{5}{|l|}{ Education } \\
\hline $\begin{array}{l}\text { Middle High } \\
\text { School }\end{array}$ & $\begin{array}{c}452.5 \\
(663.7)\end{array}$ & & $\begin{array}{c}55.2 \\
(43.1)\end{array}$ & \multirow{3}{*}{0.006} \\
\hline Diploma & $\begin{array}{c}583.1 \\
(736.4)\end{array}$ & $<0.001$ & $\begin{array}{c}142.2 \\
(445.8)\end{array}$ & \\
\hline Bachelor & $\begin{array}{c}746.7 \\
(603.7)\end{array}$ & & $\begin{array}{c}155.8 \\
(559.1)\end{array}$ & \\
\hline \multicolumn{5}{|l|}{$\begin{array}{l}\text { Monthly } \\
\text { Family Income }\end{array}$} \\
\hline$<2.000$ & $\begin{array}{l}673.8 \\
(565.3)\end{array}$ & & $\begin{array}{c}51.7 \\
(34.6)\end{array}$ & \\
\hline $2.000-5.000$ & $\begin{array}{c}1353.3 \\
(1312.7)\end{array}$ & $<0.001$ & $\begin{array}{c}92.0 \\
(134.0)\end{array}$ & $<0.001$ \\
\hline$\geq 5.000$ & 2473.9 & & 296.9 & \\
\hline
\end{tabular}


(1433.4)

$(442.7)$

\begin{tabular}{lcccc}
\hline $\begin{array}{l}\text { Social Economy } \\
\text { Status }\end{array}$ & & & & \\
\hline Low & 655.4 & & 62.0 & \\
& $(411.9)$ & & $(44.7)$ & \\
Middle & 1845.5 & & 77.8 & \\
& $(1333.1)$ & $<0.001$ & $(110.5)$ & $<0.001$ \\
High & 2243.7 & & & \\
& $(1766.3)$ & & 200.4 & \\
& & & $(444.6)$ &
\end{tabular}

The analysis result shows that education, household income, and social economy status have a significant relationship to the direct cost. Alternatively, the indirect cost has a significant relationship to only household income and social economy status. Diabetes is a chronic medical condition associated with numerous complications that makes it a substantial economic burden incurred by individuals, healthcare systems and society as a whole [14].

\section{Qualitative Analysis}

Several questions were asked to the patients, which showed that out of 15 patients, 6 of them confessed that their family encountered difficulties in escorting the patient for routine medication. This problem is caused due to the family tight schedule in working and the lack of adequate transportation to take the patient to the health facility. 10 patients stated that they often took alternative medication to ease their pain. The patients' perception towards alternative medication was quite high, which in turn, requires comprehension to DM disease. 11 patients also stated that transportation cost has become a liability to their treatment. Patients stated that transportation cost has greatly increased when the patient has to be referred to type A hospital. Furthermore, 9 patients stated that they have lost their income due to their absence in working, which caused by the increase of their blood sugar level.

Out of 15 patients, 13 amongst them have stated that they loosen their treatment schedule routine when they feel that their condition has improved to normal. Patients in normal condition are still advised to routinely taken medication to control their blood sugar level.

\section{Conclusion}

The conclusion of this research is the average cost paid by the Diabetes Mellitus type II patients as much as Rp.548.200,- monthly, monthly transportation cost of Rp. $60.300,-$ and monthly income loss of Rp.363.200,-. There was a significant relationship of education, household income, and social economy status to the direct cost. On the other hand, the indirect cost has a significant relationship to household income and the social economy status. 
Acknowledgments. Utmost gratitude is dedicated to the Ministry of Research, Technology, and Higher Education for funding this research. The appreciation is also dedicated to LL II DIKTI and Warmadewa University for providing the chance and accommodating this grant.

\section{References}

[1] Ambianti, N.: Analisis Biaya Penyakit Diabetes Melitus Sebagai Pertimbangan Perencanaan Pembiayaan Kesehatan (Tesis). Yogyakarta: Universitas Gadjah Mada (2015)

[2] Riset Kesehatan Dasar. Provinsi Bali (2007)

[3] Riset Kesehatan Dasar. Provinsi Bali (2003)

[4] Fitri, E.: Analisis Biaya Penyakit Diabetes Mellitus di RSUP Sardjito Yogyakarta (Tesis). Yogyakarta: Universitas Gadjah Mada (2015)

[5] Profil Kesehatan Provinsi Bali. Dinas Kesehatan Provinsi Bali (2014)

[6] Nuño-Solinís, Alonso-Morán, R, E., Axpe, J, M, A., Loiola, P, E., Orueta, J, F and Gaztambide, S.: Healthcare costs of people with type 2 diabetes mellitus in the Basque Country (Spain). Endocrinol. y Nutr. (English Ed. Vol. 63 (10). pp. 543-550 (2016)

[7] Lian, J, X., McGhee, S, M., Chau, J., Wong, C, K, H., Lam, C, L, K and Wong, W, C, W.: Systematic review on the cost-effectiveness of self-management education programme for type 2 diabetes mellitus. Diabetes Res. Clin. Pract. Vol. 127. pp. 21-34 (2017)

[8] Azmi, S., Goh, A., Muhammad, N, A., Tohid, H and Rashid, M, R, A.: The Cost and Quality of Life of Malaysian Type 2 Diabetes Mellitus Patients with Chronic Kidney Disease and Anemia. Value Heal. Reg. Issues. Vol. 15. pp. 42-49 (2018)

[9] Nguyen, E., Coleman, C, I., Kohn, C, G and Weeda, E, R.: Ranolazine in patients with type 2 diabetes and chronic angina: A cost-effectiveness analysis and assessment of health-related qualityof-life. Int. J. Cardiol. no. xxxx (2018)

[10] Yunus, S, Z, S, A., binti Abu Bakar, N, S., binti Musa, N, S, E., Sapian, R, A., Azahar, A and Zainuddin, N, A, binti.: Anti-diabetic drugs utilization pattern and its cost in managing Type 2 Diabetes patients in hospitals in Selangor Malaysia. Informatics Med. Unlocked. Vol. 13. pp. 21-25 (2018)

[11] Ernest, A, Q., Edward, O, A., Patricia, A and Moses, K, A.: Analysis of the Financial Cost of Diabetes Mellitus in Four Cocoa Clinics of Ghana. Elsevier. pp. 49 - 53 (2015)

[12] Charmaine, S, N., Matthias, P, H, S, T., Ko, Y and Joyce, Y,-C, L.: "Direct Medical Cost of Type 2 Diabetes in Singapore. PLoS One. Vol. 10 (3) (2015)

[13] American Diabetes Association. Economic Costs of Diabetes in the U.S. in 2012. Diabetes Care (2013)

[14] Ettaro, L., Songer, T, J., Zhang, P and Engelgau, M, M.: Cost-of-illness Studies in Diabetes Mellitus. Pharmacoeconomics. Vol. 22 (3). pp. 149-164 (2004) 